\title{
Effect of Green Oxidizing Agent on Inhibition of Escherichia coli Present in Livestock Wastes
}

\author{
Angelika Więckol-Ryk (D) • Barbara Białecka • Maciej \\ Thomas
}

Received: 22 May 2020 / Accepted: 13 August 2020 / Published online: 26 August 2020

(C) The Author(s) 2020

\begin{abstract}
The optimisation tests of sodium percarbonate (biocide) with the formula $2 \mathrm{Na}_{2} \mathrm{CO}_{3} \cdot 3 \mathrm{H}_{2} \mathrm{O}_{2}$, as a green oxidizing agent for biological deactivation of chicken manure, were carried out. The microbiological analysis of fresh manure which consisted of the enumeration of bacteria, fungi and eggs of intestinal parasites showed that the number of bacteria Enterobacteriaceae, i.e. $8.3 \log _{10} \mathrm{CFU} / \mathrm{g}$, and the bacteria $E$. coli, i.e. $6.96 \log _{10} \mathrm{CFU} / \mathrm{g}$, exceeded the required level in organic fertilizers. The Response Surface Methodology for three input parameters (biocide concentration, temperature and time) on the value of $E$. coli bacteria was applied. The obtained values of the coefficient of the multiple correlation $R^{2}$ and the adjusted coefficient $R_{\text {adj }}^{2}$ were 0.90 and 0.75 , respectively, which indicate a good fit of the data obtained with the model and the experimental data. It was concluded that a decrease in the count of the analysed microorganisms followed an increase in the sodium percarbonate concentration, an increase in the temperature and a longer time of contact of the manure sample
\end{abstract}

\footnotetext{
A. Więckol-Ryk $(\bowtie)$

Department of Risk Assessment and Industrial Safety, Central Mining Institute, Plac Gwarków 1, Katowice, Poland e-mail: awieckol@gig.eu

\section{B. Białecka}

Department of Environmental Monitoring, Central Mining Institute, Plac Gwarków 1, Katowice, Poland

M. Thomas

Chemiqua Water \& Wastewater Company, Skawińska Street 25/1, Kraków, Poland
}

with the biocide. The content of bioavailable macronutrients $(\mathrm{P}, \mathrm{N}, \mathrm{Ca}, \mathrm{Mg}, \mathrm{K})$ in water extracts of fresh chicken manure before and after its biological deactivation was determined with the ICP-OES method. The concentration of phosphorous in fresh manure extract was $310 \mathrm{mg} / \mathrm{l}$ and decreased after addition of one of the following agents: $7.5 \mathrm{wt} . \%$ of sodium percarbonate to $66.9 \mathrm{mg} / \mathrm{l}$ or $3.0 \mathrm{wt} . \%$ of traditional hygienizing agent, i.e. calcium hydroxide to $5.7 \mathrm{mg} / \mathrm{l}$.. The results of the concentration of $\mathrm{N}$ in chicken manure with sodium percarbonate was also higher than in sample with calcium hydroxide, i.e. $1040.0 \mathrm{mg} / \mathrm{l}$ and $860.0 \mathrm{mg} / \mathrm{l}$, respectively. While the addition of $2 \mathrm{Na}_{2} \mathrm{CO}_{3} \cdot 3 \mathrm{H}_{2} \mathrm{O}_{2}$ decreased the content of $\mathrm{Ca}, \mathrm{Mg}$ and $\mathrm{K}$ in fresh chicken manure.

Keywords Chicken manure - Escherichia coli . Response Surface Methodology · Sodium percarbonate

\section{Introduction}

Biowaste management is an important research issue aimed at both the economical utilization of livestock wastes as well as its effective use. In the last decade, all around the world, there has been observed a steady increase in poultry production. Poland is the European Union's third largest producer of poultry meat and hen eggs. The data published in 2017 (Statistics Poland 2017) show that the vast majority of Polish poultry production are egg laying hens and broilers $(92 \%)$; the rest are turkeys $(5.6 \%)$, ducks $(1.9 \%)$ and geese $(0.5 \%)$. 
A serious problem with the increase in poultry production is the significant amount of biowaste, i.e. manure, dead birds and slaughterhouse waste. It is also worth mentioning that poultry manure is a valuable source of nitrogen and phosphorus; hence, it is widely applied in agriculture as an organic fertilizer. Poultry waste may be applied to produce biogas in the process of anaerobic digestion (Pavlostathis and Giraldo-Gomez 1991; Williams 1999; Wu et al. 2019) in which through biochemical transformations, biogas is produced. Its main component is methane $\left(\mathrm{CH}_{4}\right)$. There are also known and applied processes of direct combustion of poultry manure to generate heat. It is estimated that the calorific value of the material depends on its moisture, the content of which in the material may vary greatly (20-50\%) and lie respectively between 9.0 and $13.5 \mathrm{GJ} /$ $\mathrm{t}$ (Dagnall et al. 2000; Kelleher et al. 2002).

One of the problems associated with using organic fertilizers in agriculture is the risk of microbiological contamination of the soil, ground waters and vegetable crops. The research showed that poultry manure contains a significant number of bacteria, viruses and fungi, as well as eggs of intestinal parasites and their spore forms. Among the number of microorganisms responsible for most pathogenic diseases, the most common ones are the following bacteria: Salmonella, Campylobacter, Yersina, Listeria monocytogenes and E. coli (Bicudo and Goyal 2003; Chen and Jiang 2014).

Pathogens may be transmitted to humans and animals through direct contact or, indirectly, through contaminated water or food. They may also spread in the air when animal manure is applied in farmlands in an uncontrolled way. The microbiological and dust tests conducted in poultry farms indicate very high content of pathogens. According to Matusiak et al. (2017), the total number of bacteria determined in fresh chicken manure showed $10^{10} \mathrm{CFU} / \mathrm{g}$ (colony forming units), and the number of fungi and moulds $10^{9} \mathrm{CFU} / \mathrm{g}$. The tests also confirm a high number of pathogens in settled dust, which for bacteria was $10^{9} \mathrm{CFU} / \mathrm{g}$ of dust and for fungi and moulds $10^{6} \mathrm{CFU} / \mathrm{g}$ of dust. The data obtained in the literature show that the content of $E$. coli bacteria in fresh poultry manure may amount to $10^{5}-10^{10} \mathrm{CFU} / \mathrm{g}$ (Diez-Gonzalez et al. 2000; Unc and Goss 2004; Kyakuwaire et al. 2019). The number of microorganisms in the samples of the litter collected from poultry farms increases as the birds get older. The tests of the litter from a broiler farm (Witkowska et al. 2010) showed an increase in the total number of microorganisms from $10^{7}$ to $10^{9} \mathrm{CFU} / \mathrm{g}$, after a few weeks of breeding broilers. It was a result of the accumulation of the birds' manure and the increased moisture of the litter.

The survival time of pathogens depends, to a large extent, on their kind and parameters of the soil, i.e. nutrients, permeability, moisture content (Olszewska 2005) and pH value (Nicholson et al. 2005). The temperature of the litter also plays a significant role. It is worth noting that low temperature stabilizes certain groups of microorganisms (Paluszak et al. 2003; Olszewska 2005; Manyi-Loh et al. 2016). In Poland, the requirements concerning the quality of fertilizers and plant growth enhancers are regulated with relevant legal acts (Minister of Agriculture and Rural Development 2008). Pursuant to those provisions, organic waste dedicated for use in agriculture must not contain Salmonella bacteria or live eggs of intestinal parasites: Ascaris sp., Trichuris sp., Toxocara sp. Additionally, the maximum permissible limits of Enterobacteriaceae bacteria must not exceed $1000 \mathrm{CFU} / \mathrm{g}$ of manure. Escherichia coli (family Enterobacteriaceae) is the predominant microaerophilic microorganism in the human and animal gut (Mawdsley et al. 1995).

The most commonly applied method of lowering the number of pathogens in animal manure is composting (Kelleher et al. 2002) and hygienizing it with chemicals. In the process of composting, i.e. decomposition of the organic matter, the number of microorganisms drops from $10^{7}$ or $10^{8} \mathrm{CFU} / \mathrm{g}$ to $10^{2}$ or $10^{3} \mathrm{CFU} / \mathrm{g}$ (Tiquia et al. 2000; Larney et al. 2003; Heinonen-Tanski et al. 2006). The process usually lasts from a few months to over a year and poses problems with storing biohazardous waste. Shortening the time, down to even $60 \mathrm{~min}$, is possible through using proper reactors, where the process hygienization is conducted at the temperature of approximately $70^{\circ} \mathrm{C}$, which is unfortunately associated with additional costs of such a process. In another often applied method of hygienization of animal manure, analogical to the process of deactivation of sewage sludge, quicklime, which is calcium oxide $(\mathrm{CaO})$, and hydrated lime, which is calcium hydroxide $\mathrm{Ca}(\mathrm{OH})_{2}$, are added (Allievi et al. 1994; Popova et al. 2014; European Lime Association 2009). The method of hygienization of sludge after fermentation, with simultaneous binding of heavy metals into poorly soluble chemical compounds (mainly hydrated hydroxides of metals), was patented in 1992 (Kalembasa et al. 1992). During the process of liming, the $\mathrm{pH}$ value rises to 
approximately 12 , and the temperature to approximately $70{ }^{\circ} \mathrm{C}$, which enables complete inactivation of bacteria and viruses present in the sludge. A disadvantage of that method is a significant loss of nitrogen compounds, which are volatilized in a form of ammonia, which results in a decrease in the concentration of nitrogen in the final fertilizer. The conducted research has shown that the content of phosphorus in poultry manure is a few times lower than the content of nitrogen, and as much as eight times higher than crops require. The presented dependences are confirmed by numerous literature data concerning the determined percentage of nitrogen/phosphorus, which were respectively as follows: 6.0/1.8 (Nicholson et al. 1996), 3.4/0.6 (Omeira et al. 2006), 5.9/0.65 (Quiroga et al. 2010) and 2.57/6.7 (Baki Unal et al. 2015). A side effect of continuous use of raw poultry manure to fertilize farmlands is the disturbance to the ecosystem equilibrium and eutrophication of water reservoirs (Correll 1998).

One solution to the problem is refraining from liming fresh poultry manure and, as a result, limiting losses of nitrogen. That is why attempts have been made to apply such technologies which will enable lowering the number of pathogenic microorganisms at a minimal loss of nitrogen. The research into the application of calcium peroxide addition to fresh manure enabled the binding moisture by over $20 \%$ (Qu et al. 2018), yet it did not show any positive effect of inactivating bacteria in litter manure from broiler farms (Mituniewicz et al. 2016). It was probably caused by too low concentration of $\mathrm{CaO}_{2}$ which was only $2 \mathrm{~g} / \mathrm{m}^{2}$ of the surface inhabited by the microorganisms.

The positive effect of reducing the number of bacteria, of the initial concentration of $10^{6} \mathrm{CFU} / \mathrm{g}$ in cow manure, was obtained after a few days of contact of the analysed material with the addition of sodium carbonate $\left(\mathrm{Na}_{2} \mathrm{CO}_{3}\right)$ and ammonium compounds (Diez-Gonzalez et al. 2000; Arthurs et al. 2001; Park and Diez-Gonzalez 2003). Satisfactory lowering of the number of mezophilic bacteria by $99.9 \%$ in the liquid fraction of pig slurry was obtained after a 24-h exposure of the sample with an addition of $2 \%$ solution of hydrogen peroxide $\left(\mathrm{H}_{2} \mathrm{O}_{2}\right)$ with monovalent silver ions (Tofant et al. 2003). The literature also describes other effective methods of deactivation of pathogens, such as UV radiation (Płonka and Pieczykolan 2020). However, this method is used mainly for water and wastewater disinfection and has not been applied for animal waste, due to high operating costs.
The development of an effective method of biological deactivation of poultry manure with environmentally friendly and biodegradable chemicals still presents a challenge for many researchers who deal with the issue.

The article presents the research into optimizing the process of biological deactivation of poultry manure with sodium percarbonate as a biocide with the formula $2 \mathrm{Na}_{2} \mathrm{CO}_{3} \cdot 3 \mathrm{H}_{2} \mathrm{O}_{2}$, which may offer an interesting alternative to the commonly applied calcium compounds as a new green oxidizing agent.

\section{Material and Methods}

\subsection{Material}

The samples of fresh chicken manure were collected in January 2019. They came from a Polish egg laying hen farm located in Silesia region. During the research, there were 52 thousands birds of age of up to 16 weeks. The farm consisted of five buildings with the birds in the cage system and five buildings in the deep litter system. The cages were cleaned of the manure once a week, and the litter with manure was changed once every production cycle, i.e. every 17-18 weeks.

The samples were selected randomly from fresh prisms of manure from the cage system. The laboratory sample was then prepared with a split method according to the standard PN-R-04006:2000. An average 1-kg laboratory sample was immediately transported to the laboratory and tested and stored at the temperature of 4 to $5{ }^{\circ} \mathrm{C}$ until the tests.

The sodium percarbonate $\left(2 \mathrm{Na}_{2} \mathrm{CO}_{3} \cdot 3 \mathrm{H}_{2} \mathrm{O}_{2}\right.$, Brenntag, Poland) as the green deactivating agent and calcium hydroxide $\left(\mathrm{Ca}(\mathrm{OH})_{2}\right.$, Chempur, Poland) as the traditional hygienizing agent were applied.

\subsection{Analysis of Fresh Chicken Manure}

The microbiological analysis was conducted at the room temperature of $20{ }^{\circ} \mathrm{C}$, right after delivering the raw sample to the laboratory. Four 10 -g test portions were taken from the laboratory sample of raw manure. One of them was dedicated directly for laboratory tests concerning the microbiological analysis, moisture content and $\mathrm{pH}$. The remaining three samples were placed in sterile vessels and stored for $2 \mathrm{~h}$ in the desiccator, set at the temperature of 40,70 and $105{ }^{\circ} \mathrm{C}$, respectively. The microbiological analysis of the samples of chicken 
manure was conducted with the serial dilution method, applying the spread plate method. A representative 10-g test portion of the analysed material was suspended in $90 \mathrm{ml}$ of sterile saline $(0.85 \% \mathrm{NaCl})$. The samples were shaken for $10 \mathrm{~min}$, and then further decimal dilutions from $10^{-1}$ to $10^{-7}$ were prepared. The $0.1-\mathrm{ml}$ samples were spread on proper microbiological media and incubated following the requirements of the relevant standards. After the incubation period, the microbial count $(M C)$ was calculated with Eq. (1), and the obtained result is presented as $\log _{10}$ CFU in $1 \mathrm{~g}$ of the tested manure:

$M C=\frac{a}{b} \cdot\left(10^{-x}\right)^{-1}$

where $a$ is the number of colonies, $b$ is the volume of spread sample and $10^{-x}$ is the dilution coefficient.

The following media were applied in the tests: TSA (Tryptic Soy Agar) for the total number of microorganisms, according to EN ISO 4833-1:2013; RBA (Rose Bengal Agar) for the total number of fungi and moulds according to ISO 21527-1:2008; Endo (Endo Agar) for the total number of $E$. coli bacteria; TBX (Tryptone Bile Glucuronic Agar) for the number of beta-glucuronidasepositive E. coli according to ISO 16649-1:2018; MSRV (Modified Semi-Solid Rappaport-Vassiliadis) for occurrence of Salmonella; and VRBG (Violet Red Bile Glucose) for the number of bacteria Enterobacteriace$a e$. The number of live eggs of intestinal parasites AT (Ascaris ssp., Trichuris ssp., Toxocara ssp.) was determined with the flotation method according to the standard PN-Z-19005:2018.

The moisture content in the raw sample was determined by drying it to a constant weight at the temperature of $105{ }^{\circ} \mathrm{C}$. The value of $\mathrm{pH}$ of the raw sample and the sample of manure treated with $10 \mathrm{wt} . \%$ of sodium percarbonate was determined by potentiometry following the standard EN 12176:1998.

\subsection{Effect of Sodium Percarbonate on the Survival of $E$. coli}

A weight of a $10 \mathrm{~g}$ sample of fresh chicken manure was added to the amount of sodium percarbonate in accordance within the plan of the experiment (Table 1). The content of green oxidizing agent in the mixture was from 3.3 to 11.7 wt. $\%$, while the storage time and temperature of the experiments were from 7.1 to $208.9 \mathrm{~h}$ and from 5.2 to $38.8^{\circ} \mathrm{C}$, respectively. Each of the mixtures ( $1 \mathrm{~g}$ per sampling) was shaken for $10 \mathrm{~min}$ in $9 \mathrm{ml}$ of sterile saline $(0.85 \% \mathrm{NaCl})$ and serially diluted (1:10). The volume of $0.1 \mathrm{ml}$ from each dilutions
Table 1 Experimental conditions and results of central composite design

\begin{tabular}{|c|c|c|c|c|}
\hline $\begin{array}{l}\text { Number of the } \\
\text { experiment }\end{array}$ & $\begin{array}{l}\text { Concentration of } \\
2 \mathrm{Na}_{2} \mathrm{CO}_{3} \cdot 3 \mathrm{H}_{2} \mathrm{O}_{2} \text {, wt. } \% \\
x_{1}\end{array}$ & $\begin{array}{l}\text { Temperature, } \\
{ }^{\circ} \mathrm{C} \\
x_{2}\end{array}$ & $\begin{array}{l}\text { Time, } \mathrm{h} \\
x_{3}\end{array}$ & $\begin{array}{l}\text { E. coli, } \log _{10} \\
\text { CFU/g } \\
Z\end{array}$ \\
\hline 1 & 5.0 & 12.0 & 48.0 & 6.959 \\
\hline 2 & 5.0 & 12.0 & 168.0 & 5.708 \\
\hline 3 & 5.0 & 32.0 & 48.0 & 6.322 \\
\hline 4 & 5.0 & 32.0 & 168.0 & 5.940 \\
\hline 5 & 10.0 & 12.0 & 48.0 & 4.875 \\
\hline 6 & 10.0 & 12.0 & 168.0 & 2.944 \\
\hline 7 & 10.0 & 32.0 & 48.0 & 3.301 \\
\hline 8 & 10.0 & 32.0 & 168.0 & 2.301 \\
\hline 9 & 3.3 & 22.0 & 108.0 & 5.892 \\
\hline 10 & 11.7 & 22.0 & 108.0 & 3.398 \\
\hline 11 & 7.5 & 5.2 & 108.0 & 4.799 \\
\hline 12 & 7.5 & 38.8 & 108.0 & 2.255 \\
\hline 13 & 7.5 & 22.0 & 7.1 & 5.623 \\
\hline 14 & 7.5 & 22.0 & 208.9 & 3.000 \\
\hline $15(\mathrm{C})$ & 7.5 & 22.0 & 108.0 & 3.602 \\
\hline $16(\mathrm{C})$ & 7.5 & 22.0 & 108.0 & 3.531 \\
\hline
\end{tabular}


was poured onto Petri dishes with Endo agar and incubated at the temperature of $38 \pm 1{ }^{\circ} \mathrm{C}$ for $24 \pm 2 \mathrm{~h}$.

After the incubation period, the grown colonies of E. coli bacteria were counted (circular, smooth red colonies with metallic shine), and the result obtained was presented as $\log _{10} \mathrm{CFU}$ in $1 \mathrm{~g}$ of the analysed manure.

\subsection{Response Surface Methodology}

Optimisation of the process of inactivating chicken manure with sodium percarbonate was conducted with Response Surface Methodology (Myers et al. 2016). Following the Box-Behnken design (Box et al. 2005), the plan of the experiment was prepared for three independent variables: concentration of biocide $\left(x_{1}, \mathrm{wt} \%\right)$, exposure time $\left(x_{2}, \mathrm{~h}\right)$ and the process temperature $\left(x_{3},{ }^{\circ} \mathrm{C}\right)$. The number of $E$. coli bacteria $\left(Z, \log _{10} \mathrm{CFU} / \mathrm{g}\right)$ was assumed as a dependant variable which is a response of the setup. Applying Statistica 10 software and its module for the design of experiments (DOE), a three-factor central composite design was drafted, consisting of 16 experiments. Experiments 1-14 concerned changes in the value of the independent variables in the vertices of the area, and experiments 15 (C)-16 (C) concerned the middle of the 3D area, i.e. the centre of the plan, and they were to determine the measurement error. Basing on the analysis of the results of the initial tests, the following values of the independent variables were assumed:

$$
\begin{gathered}
\mathrm{x} 1 \in<3.3 ; 11.7> \\
\mathrm{x} 2 \in<7.1 ; 209.0> \\
\mathrm{x} 3 \in<5.0 ; 38.0>
\end{gathered}
$$

The verification of the significance of given coefficients of the approximating function was conducted with a Student's $t$ test and ANOVA. The coefficient of determination $R^{2}$, adjusted coefficient of determination $R_{\mathrm{adj}}{ }^{2}$ and the root mean square error (RMSE) of the socalled fitting error variance were determined. Response surface plots were drawn, which enable forecasts of the changes in the estimated values, depending on the changes in the input values. The second-degree polynomials (Eq. (2)) was calculated to estimate the response of three independent variables $x_{1}, x_{2}, x_{3}$ had the following form:

$$
\begin{aligned}
Z= & \beta_{0}+\beta_{1} x_{1}+\beta_{1} x_{1}^{2}+\beta_{3} x_{2}+\beta_{4} x_{2}^{2}+\beta_{5} x_{3} \\
& +\beta_{6} x_{3}^{2}+\beta_{7} x_{1} x_{2}+\beta_{8} x_{1} x_{3}+\beta_{9} x_{2} x_{3}+\varepsilon
\end{aligned}
$$

where: $\beta$ - coefficients of the model (contribution of the independent variable in forecasts of variable $Y$ );

$\varepsilon$-random experimental error of normal distribution;

$x_{1}$-concentration of sodium percarbonate, wt. $\%$;

$x_{1}$-temperature, ${ }^{\circ} \mathrm{C}$;

$x_{1}$-time, h.

\subsection{Determination of Water-Soluble Macronutrients}

A weighted amount of $40 \mathrm{~g}$ dry matter (d.m.) of fresh chicken manure and also $40 \mathrm{~g}$ d.m. manure with 7.5 wt. $\%$ of $2 \mathrm{Na}_{2} \mathrm{CO}_{3} \cdot 3 \mathrm{H}_{2} \mathrm{O}_{2}$ and 3.0 wt. $\%$ $\mathrm{Ca}(\mathrm{OH})_{2}$ were placed into three $500 \mathrm{~cm}^{3}$ bottles. Then the samples were added into deionized water in ratio $1: 10$ and shaken on a rotary mixer at a speed of $40 \mathrm{rpm}$ for 8 hours.

The samples were then centrifuged for at $15000 \mathrm{rpm}$ for 15 min (SIGMA 3K30) and filtered using Whatman $0.45 \mu \mathrm{m}$ filters. The water extract from fresh chicken manure was marked with the symbol R0 (control sample), and the extracts from chicken manure with $2 \mathrm{Na}_{2} \mathrm{CO}_{3} \cdot 3 \mathrm{H}_{2} \mathrm{O}_{2}$ and $\mathrm{Ca}(\mathrm{OH})_{2}$ were marked as $\mathrm{R} 1$ and $\mathrm{R} 2$, respectively.

The determination of total macronutrients $(\mathrm{P}, \mathrm{N}, \mathrm{Ca}$, $\mathrm{Mg}$ and $\mathrm{K}$ ) in water extracts complied with the leaching procedure for solid waste materials according to the standard PN-EN 12457-2:2004. The content of macronutrients in extracts was determined by the ICP-OES method using the Perkin Elmer Optima 5300 ICP-OES analyser. The $\mathrm{pH}$-value was measured by using the $\mathrm{pH}$ meter (CPC-411) with the glass electrode IJ44AT (Elmetron, Poland).

\section{Results and Discussion}

3.1 Influence of the Increase in Temperature on the Number of Microorganisms

The measured $\mathrm{pH}$ value of the fresh sample was 6.26, and the content of dry matter was $37.48 \%$. The conducted microbiological analysis of the samples of fresh poultry manure from a cage system poultry farm showed that the acceptable numbers of pathogenic microorganisms were significantly exceeded. The results of microbiological analyses for the given types of microorganisms are presented in Fig. 1. Following the requirements of the regulation (Minister of Agriculture and Rural Development 2008), the number of Enterobacteriaceae bacteria in 
Fig. 1 Microbial count in fresh chicken manure depending on storage temperature

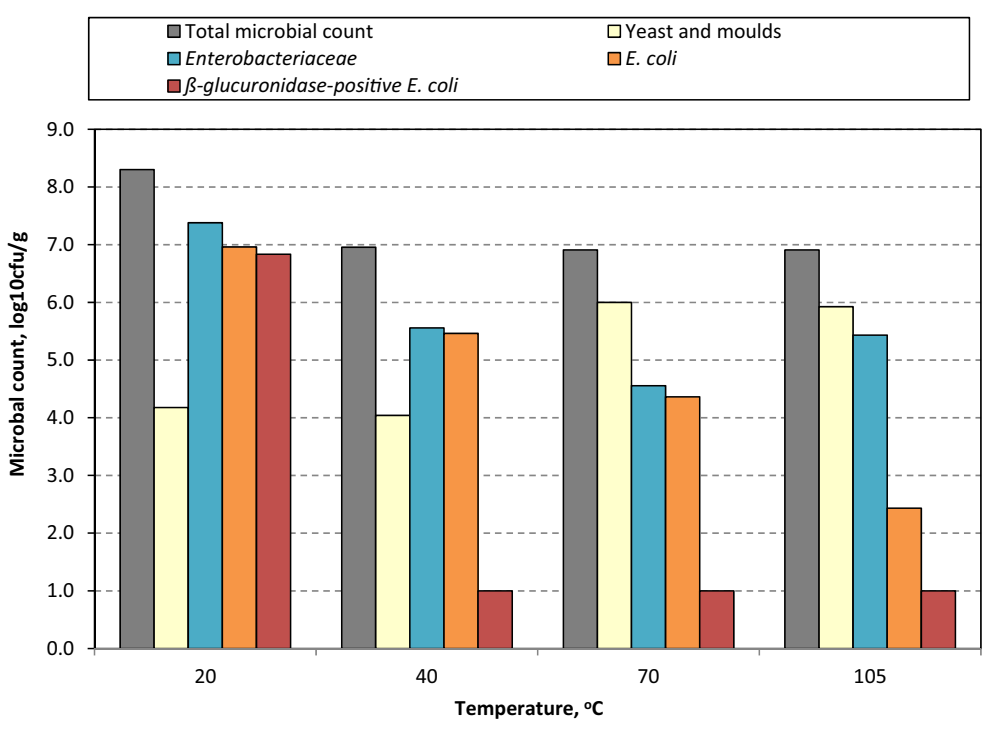

natural fertilizers cannot exceed to $3 \log _{10} \mathrm{CFU} / \mathrm{g}$. The total number of microorganisms in the sample of manure analysed directly after its arrival at the laboratory and stored at the temperature of $20{ }^{\circ} \mathrm{C}$ was $8.3 \log _{10} \mathrm{CFU} / \mathrm{g}$, and the number of Enterobacteriaceae bacteria was $7.38 \log _{10} \mathrm{CFU} / \mathrm{g}$. A decrease in the number of microorganisms was observed in the samples of manure subjected to higher temperature. The number of Enterobacteriaceae decreased, on average, by $25 \%$ to $5.56 \log _{10} \mathrm{CFU} / \mathrm{g}$ at $40{ }^{\circ} \mathrm{C}, 4.56 \log _{10} \mathrm{CFU} / \mathrm{g}$ at $70{ }^{\circ} \mathrm{C}$ and $5.43 \log _{10} \mathrm{CFU} / \mathrm{g}$ at $105{ }^{\circ} \mathrm{C}$, respectively. A significant influence of the temperature on the number of $E$. coli bacteria was observed, which was $6.96 \log _{10} \mathrm{CFU} / \mathrm{g}$ in the fresh sample, and in the sample subjected to the temperature of $105^{\circ} \mathrm{C}$, it decreased to $2.43 \log _{10} \mathrm{CFU} / \mathrm{g}$. The higher temperature also showed to have a positive effect on the reduction ratio of the beta-glucuronidase-positive E. coli bacteria. The number of the pathogens decreases from $6.83 \log _{10} \mathrm{CFU} / \mathrm{g}$ at $20{ }^{\circ} \mathrm{C}$ to $1.0 \log _{10} \mathrm{CFU} / \mathrm{g}$ at $40{ }^{\circ} \mathrm{C}$. The results of the analyses of the total number of yeast and moulds showed that the higher temperature of storage of poultry manure may positively affect their reproduction. The measured number of the microorganisms increased by $40 \%$ from $4.17 \log _{10} \mathrm{CFU} / \mathrm{g}$ at the temperature of $20{ }^{\circ} \mathrm{C}$ to $5.92 \log _{10} \mathrm{CFU} / \mathrm{g}$ at $105^{\circ} \mathrm{C}$.

Moreover, in the tested samples, neither Salmonella rods nor live eggs of intestinal parasites were observed. Photographs of the colonies of microorganisms grown at the temperature of $20^{\circ} \mathrm{C}$ from a sample of fresh manure from a cage system poultry farm are presented in Fig. 2.
3.2 Effect of the Addition of Sodium Percarbonate on the Number of $E$. coli Bacteria

Sodium percarbonate is a chemical substance of highly oxidizing properties. It has the same advantages as the liquid hydrogen peroxide. The compound contains at least 88 wt. $\%$ of $2 \mathrm{NaCO}_{3} 3 \mathrm{H}_{2} \mathrm{O}_{2}$ and approximately $12 \mathrm{wt} . \%$ of $\mathrm{Na}_{2} \mathrm{CO}_{3}$. The solution of concentration of $3 \%$ has the $\mathrm{pH}$ value of 10-11. Sodium percarbonate is considered a green oxidant that decomposes into hydrogen peroxide and sodium carbonate. Dissolved in water, sodium percarbonate is broken down that releases an active oxygen (Eq. (3)), which demonstrates the disinfecting properties:

$$
\begin{gathered}
2 \mathrm{Na}_{2} \mathrm{CO}_{3} \cdot 3 \mathrm{H}_{2} \mathrm{O}_{2} \rightarrow 4 \mathrm{Na}^{+}+2 \mathrm{CO}_{3}^{2-}+3 \mathrm{H}_{2} \mathrm{O}_{2} \\
2 \mathrm{H}_{2} \mathrm{O}_{2} \rightarrow 2 \mathrm{H}_{2} \mathrm{O}+\mathrm{O}_{2}
\end{gathered}
$$

Hydrogen peroxide is rapidly degraded in a soil, while sodium carbonate will be neutralized (USDA 2014).

Sodium percarbonate can be used for effective treatment of industrial sewage through oxidising organic substances, even resistant to decomposition (Barbusiński 2008; Thomas et al. 2017). This agent is harmless for the environment, and it is not bioaccumulated in soil and ground waters. The results of the research into the optimization of the process of deactivating chicken manure with $2 \mathrm{NaCO}_{3} 3 \mathrm{H}_{2} \mathrm{O}_{2}$ are presented in Table 1.

The lowest number of $E$. coli bacteria was obtained in experiment 12 , where the temperature of storing the 
Fig. 2 Colonies formed by microorganisms grown from a sample of fresh manure on given media: a yeast and moulds (Rose Bengal Agar), b

Enterobacteriaceae (Violet Red Bile Glucose), c Escherichia coli (Endo Agar) and $\mathbf{d} \beta$ glucuronidase positive Escherichia coli (Tryptone Bile Glucuronic Agar)
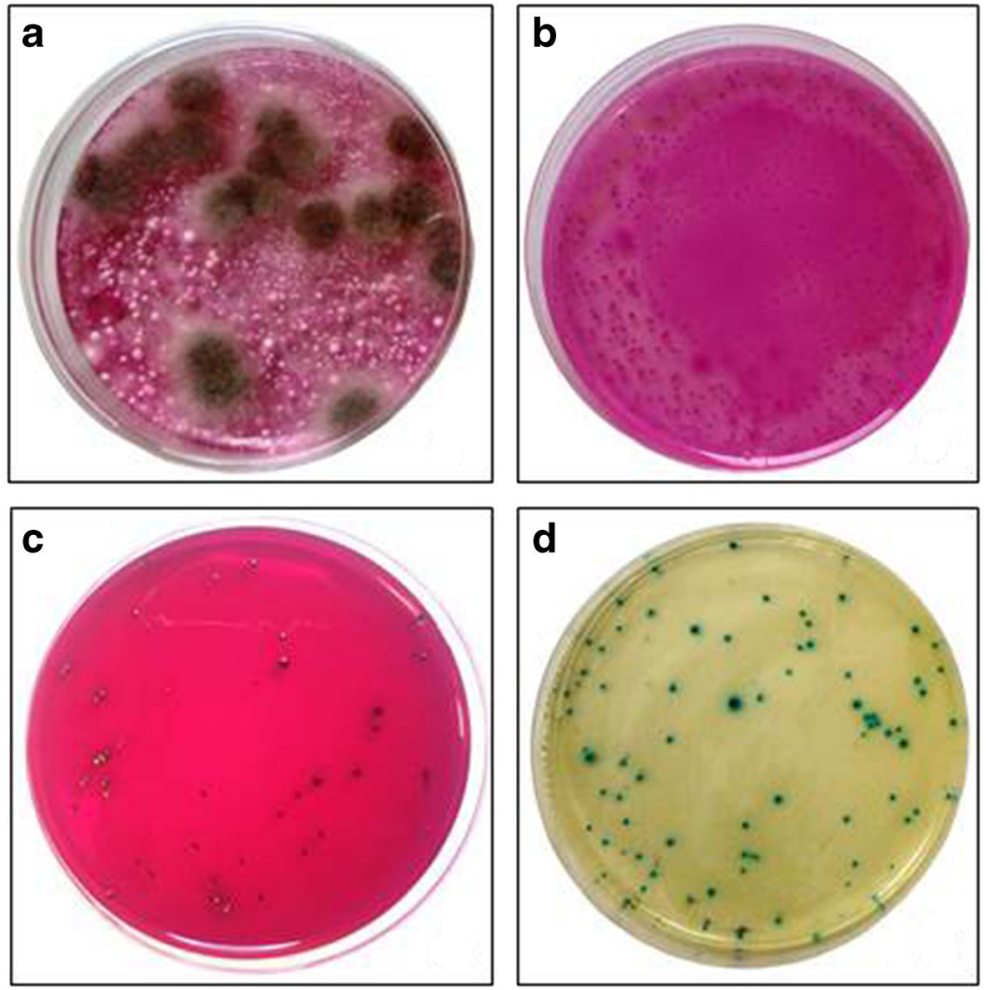

sample with sodium percarbonate was $38^{\circ} \mathrm{C}$ and the time of contact of the mixture was $108 \mathrm{~h}$. The highest survivability of the pathogen was observed in experiment 1 , where the biocide content was $5 \mathrm{wt} \%$ and the time and temperature were $48 \mathrm{~h}$ and $12{ }^{\circ} \mathrm{C}$, respectively.

For the experiments in the centre of the plan 15 (C) and $16(\mathrm{C})$, similar numbers of grown E. coli bacteria were obtained, 3.602 and $3.531 \log 10 \mathrm{CFU} / \mathrm{g}$ respectively, similar values of the number of grown $E$. coli bacteria were obtained, of respectively 3.602 and $3.531 \log _{10} \mathrm{CFU} / \mathrm{g}$. It shows only slight differences for the same values of the input.

The results of the statistical analysis, ANOVA test, together with estimators of effects and the coefficients of the model of the inputs are presented in Table 2. The model of the process was built as a second-degree polynomial, containing the main linear $(\mathrm{L})$ and square (Q) effects together with two-factor interactions $(1 \mathrm{~L} \mathrm{i} / \mathrm{o}$ $2 \mathrm{~L}, 1 \mathrm{~L}$ i/o $3 \mathrm{~L}, 2 \mathrm{~L} \mathrm{i} / \mathrm{o} 3 \mathrm{~L}$ ). The obtained value of the calculated coefficient of determination $R^{2}$ was close to 1 with the actual value of 0.90 . The value of the adjusted coefficient $R_{\text {adj. }}{ }^{2}$, which always indicates better fitting of the model and is lower than $R^{2}$, was 0.75 . It means that the determined regression plan demonstrated a good fit to the experimental data. The conducted statistical analysis showed two statistically significant parameters, i.e. concentration of sodium percarbonate (L) and the time of contact of a tested sample with the biocide (L). The other parameters were statistically non-significant, and the value of $p$ in each of the cases was higher than 0.05 . The results of the analysis are presented in Table 2 .

Further analyses were conducted on all the main linear-square effects, whereas insignificant effects of linear-linear interactions were excluded (i.e. $1 \mathrm{~L}$ i/o $2 \mathrm{~L}, 1 \mathrm{~L}$ i/o $3 \mathrm{~L}$ and $2 \mathrm{~L} \mathrm{i} / \mathrm{o} 3 \mathrm{~L}$ ). A reconducted statistical analysis confirmed a significance of the four coefficients, i.e. constant value, concentration (L), temperature $(\mathrm{Q})$ and time $(\mathrm{L})$. Despite excluding linear-linear interactions, a very good fit of the model to the experimental data was obtained; the value of calculated coefficient of determination $R^{2}$ was 0.87 , and the adjusted coefficient of determination $R_{\mathrm{adj}}{ }^{2}$ was 0.79 . The value of mean square error was 0.5025 . The results of the verification of the fit of the model using the ANOVA test showed three significant input parameters, i.e. concentration of sodium percarbonate $(\mathrm{L})$, temperature $(\mathrm{L})$ and time (L). The detailed results of the analysis are presented in Table 3.

The verification of the quality of fit of the experimental data to the developed model is presented in a 

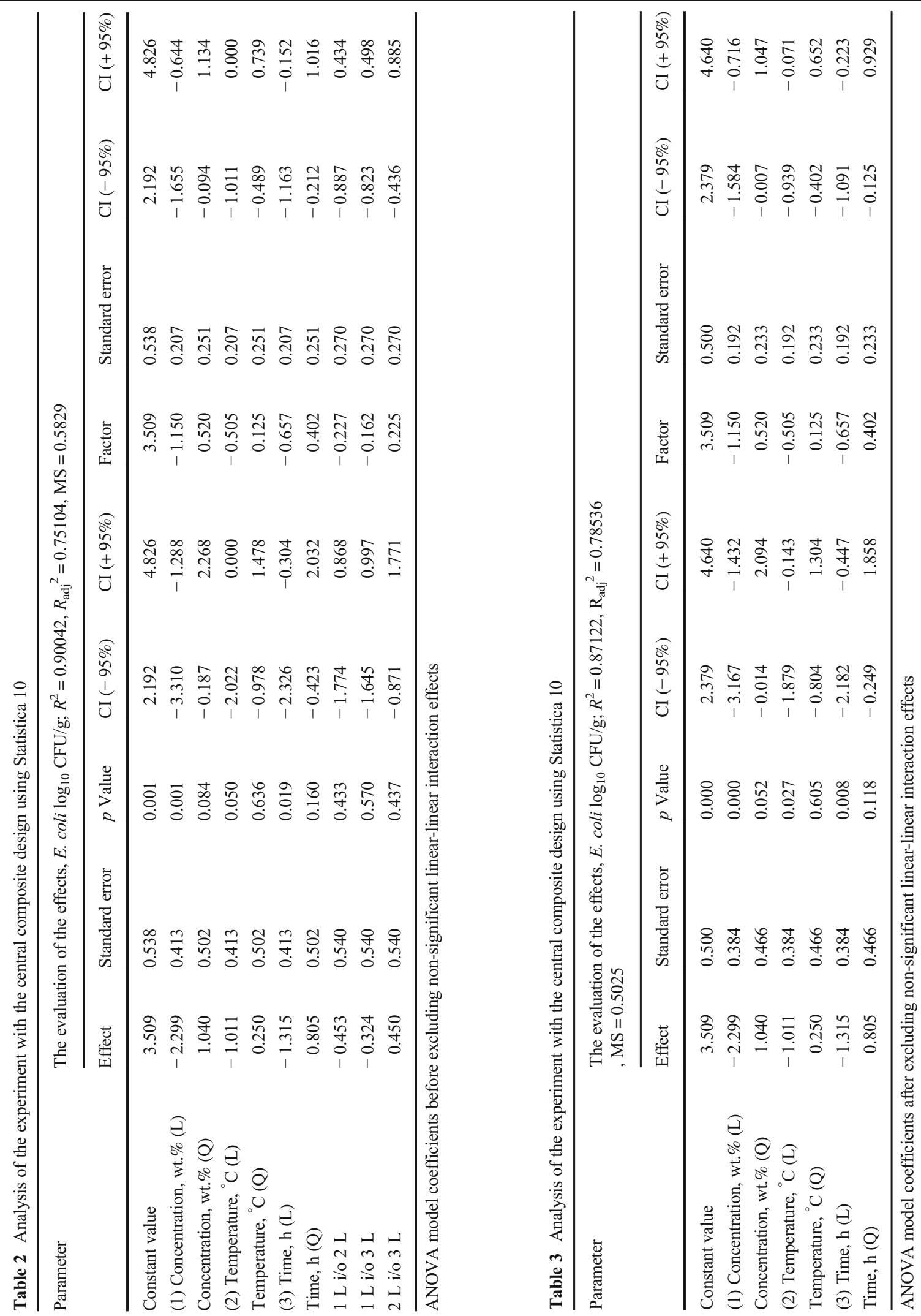
graphic form with a Pareto chart (Fig. 3). It presents estimators of standardized effects grouped according to their absolute value. The vertical red line represents the minimal statistical values of significant effects, at the level of significance of the estimated values on the observed values $(\alpha=0.05)$. The statistical analysis showed a significance of the three main factors, i.e. concentration (L), time (L) and temperature (L), and a statistical insignificance or low statistical significance of the three other factors, i.e. concentration (Q), time (Q) and temperature $(\mathrm{Q})$.

For the visual verification of the quality of fit of the experimental data to the developed model, excluding irrelevant effects of linear-linear interactions, a graph was drawn up showing the dependences of the estimated values on the observed values. It is presented in Fig. 4.

The presented graph indicates the good fit of the values and is proper for the obtained experimental data. The points indicating the experimental data are located close to the line representing the approximated values.

In the next stage of the statistical analysis, response surface 3D plots were drawn to describe the values estimated at a given value of one input variable and changed two other input variables. The shapes of the prepared response surfaces formed the basis for the analyses of the influence of the given factors on the number of pathogens marked in the samples. The response surface plots describing the influence of biocide concentration, the process temperature and the contact time on the number of $E$. coli bacteria in the mixture of manure and sodium percarbonate are presented in Figs. 5, 6 and 7.

The mathematical description of Fig. 5, presenting a change in value $Z$ (E. coli $\left.\log _{10} \mathrm{CFU} / \mathrm{g}\right)$ as a function of $x_{1}$ (concentration of sodium percarbonate) on $x_{3}$ (time) at the assumed constant temperature $x_{2}$ of $22{ }^{\circ} \mathrm{C}$, is presented in Eq. (4):

$$
\begin{aligned}
Z= & 15.8425-1.7082 \cdot x_{1}+0.0832 \cdot x_{1}^{2}-0.0351 \cdot x_{3} \\
& +0.001 \cdot x_{3}^{2}-1.7165
\end{aligned}
$$

The conducted analysis shows that the sodium percarbonate at the concentration of $3 \mathrm{wt} . \%$ and below does not present any significant biocidal activity which would be measurable with the applied method. The number of E. coli bacteria was within the range of $8^{-}$ $9 \log _{10} \mathrm{CFU} / \mathrm{g}$, which roughly corresponds with the number of the pathogens in a raw sample without a biocide. A slight effect of lowering of the number of bacteria below $7 \log _{10} \mathrm{CFU} / \mathrm{g}$ was observed at the concentration greater than $4 \mathrm{wt} \%$; however, the effect was obtained only after $40-50 \mathrm{~h}$ contact of the sample with the biocide. Adding more sodium percarbonate to a raw sample, 5-7 wt.\%, enabled a reduction of the number of bacteria to the level of $5 \log _{10} \mathrm{CFU} / \mathrm{g}$ and lower, and the effect was obtained as soon as after $20 \mathrm{~h}$ of the contact with the biocide. The lowest number of bacteria, below $3 \log _{10} \mathrm{CFU} / \mathrm{g}$, was

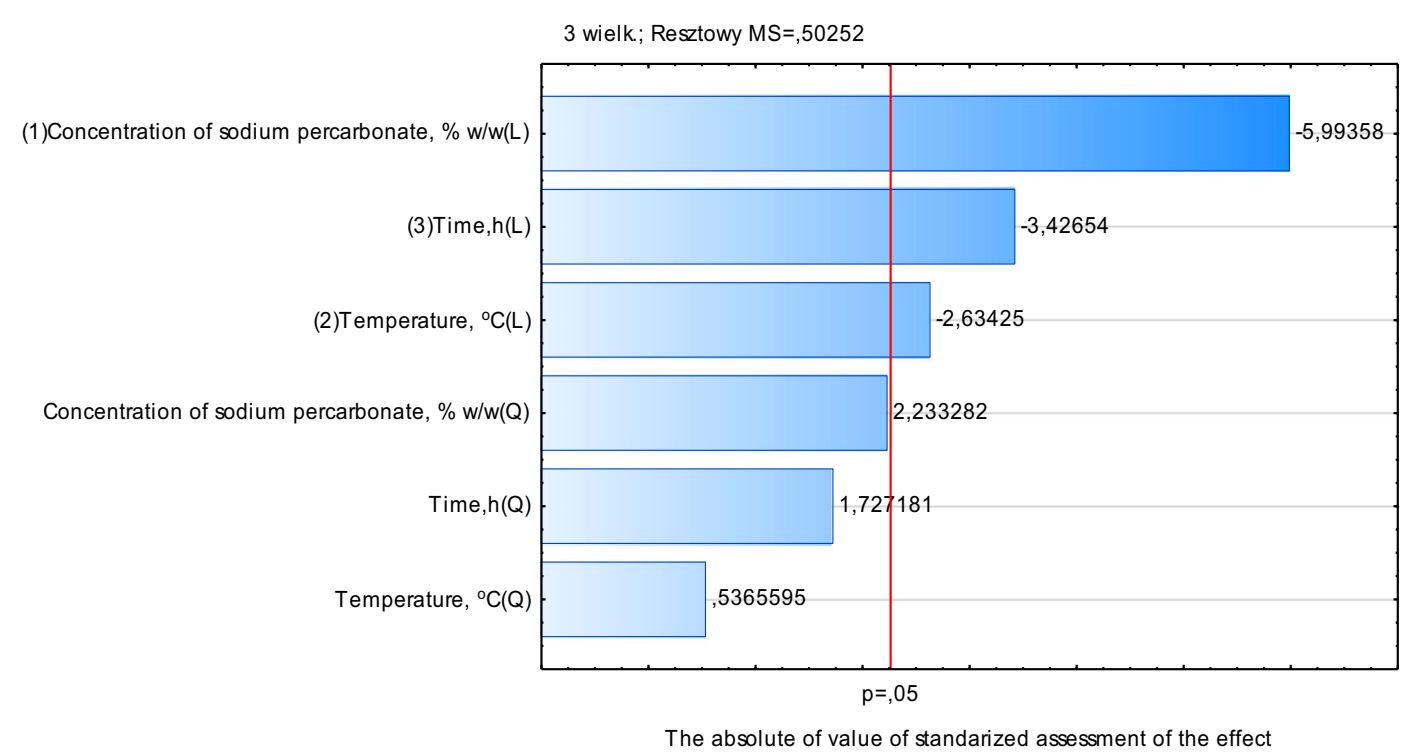

Fig. 3 Pareto chart - the absolute value of standardized assessment of the effects $\left(E\right.$. coli, $\log _{10} \mathrm{CFU} / \mathrm{g}, 3$ values, 1 block, 16 experiments, $\mathrm{MS}=0.5025)$ 
Fig. 4 The correlation between estimated and observed values (E. coli, $\log _{10} \mathrm{CFU} / \mathrm{g}, 3$ values, 1 block, 16 experiments, $\mathrm{MS}=$ 0.5025 )

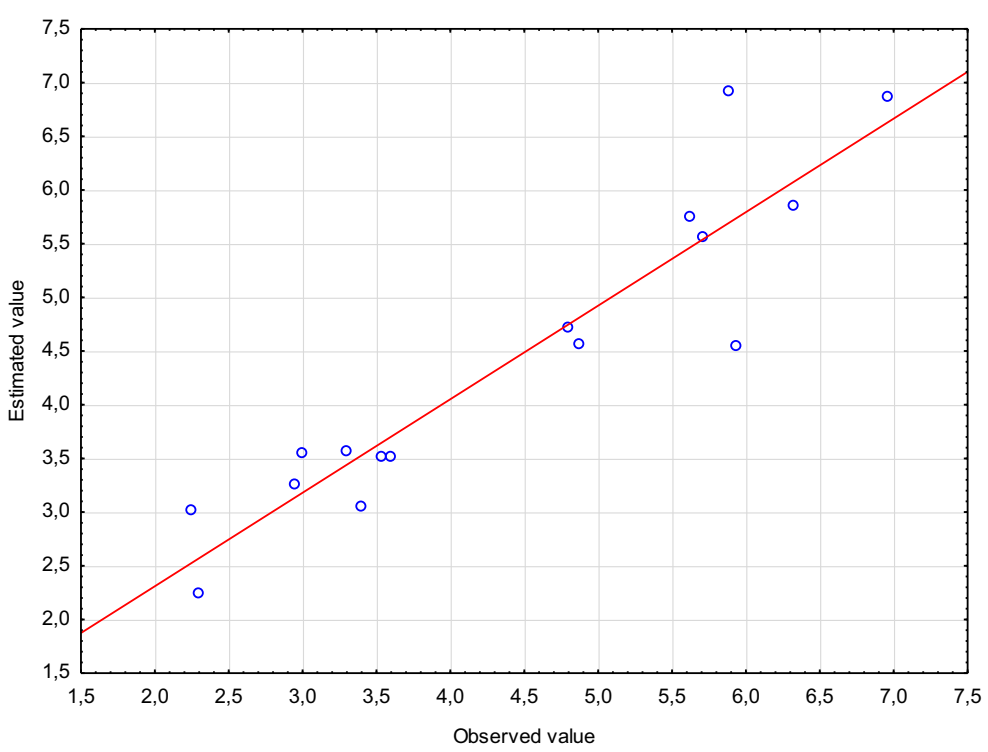

determined in the samples of sodium percarbonate concentration of $8 \mathrm{wt} . \%$ and the contact of over $100 \mathrm{~h}$. Moreover, independently of the amount of the applied biocide, a slight increase in the number of bacteria was observed after $160 \mathrm{~h}$. It may have been associated with the end of releasing active oxygen, which deactivates pathogens, as well as a possible survival of $E$. coli bacteria in manure for the period of a few months or even over 1 year. The result confirms the findings of numerous publications where it was proved that the survival time of $E$. coli bacteria in animal manure depends on its storage temperature and it may vary between a few weeks and a few months (Kudva et al. 1998; Jiang et al. 2002; Jung et al. 2013).

The mathematical description of Fig. 6, presenting a change in the value of $Z$ (E. coli $\left.\log _{10} \mathrm{CFU} / \mathrm{g}\right)$ as a function of $x_{1}$ (concentration of sodium percarbonate,
Fig. 5 Response surface 3D plots of the influence of concentration of sodium percarbonate and its contact time on the number of E. coli bacteria in chicken manure $(\mathrm{MS}=0.5025)$

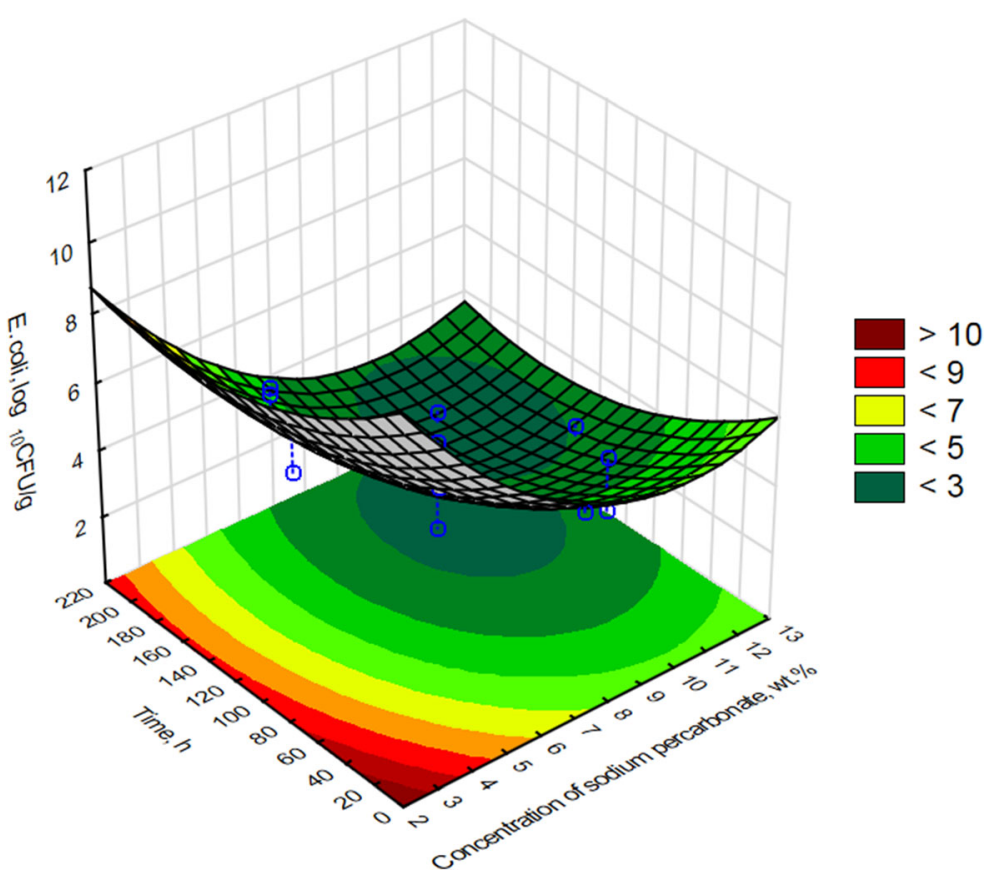


Fig. 6 Response surface of the effect of the concentration of sodium percarbonate and the process temperature on the number of $E$. coli bacteria in poultry manure $(\mathrm{MS}=0.5025)$

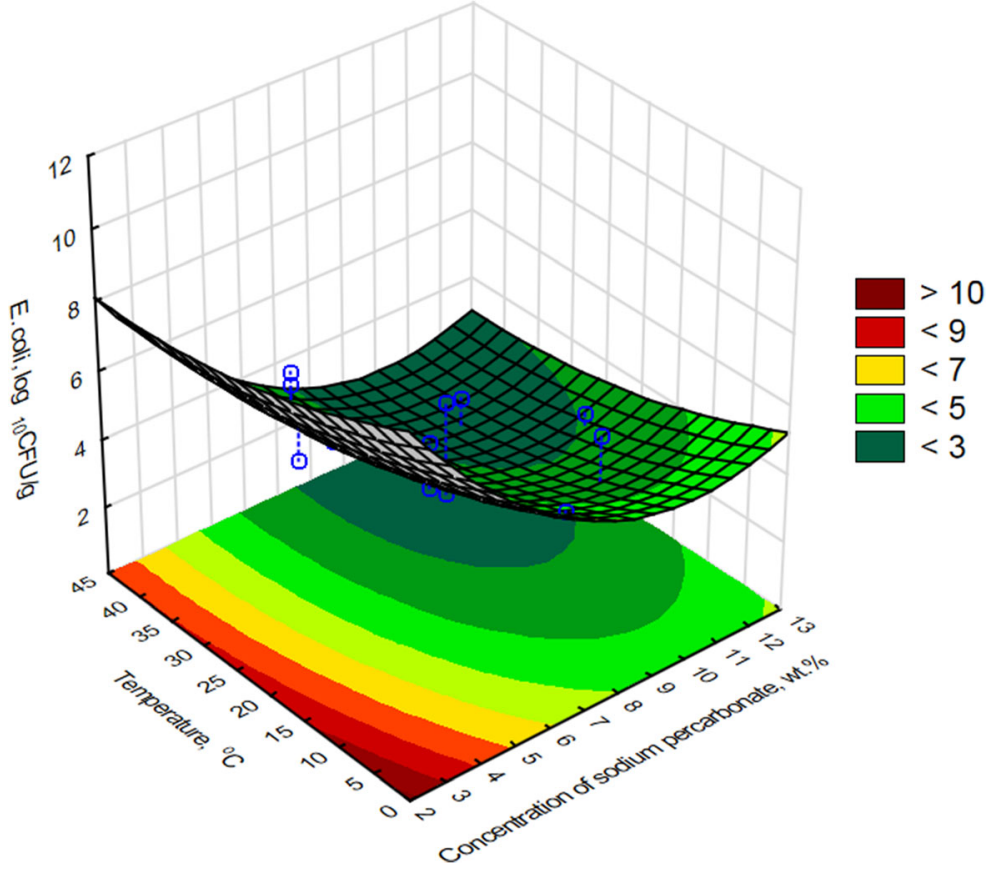

$\mathrm{wt} \%$ ) on $x_{2}$ (temperature, ${ }^{\circ} \mathrm{C}$ ) at the assumed constant time $x_{2}$ of $108 \mathrm{~h}$, is presented in Eq. (5):

$$
\begin{aligned}
Z= & 15.8425-1.7082 \cdot x_{1}+0.0832 \cdot x_{1}^{2}-0.1055 \bullet x_{2} \\
& +0.0012 \cdot x_{2}^{2}-2.4865
\end{aligned}
$$

The analysis of the influence of the concentration of sodium percarbonate and the temperature, presented in
Fig. 6, confirmed a lack of any significant reduction of the number of $E$. coli bacteria at the biocide concentration below 3 wt. $\%$, which was $9 \log _{10} \mathrm{CFU} / \mathrm{g}$. As the biocide concentration increased over $5 \mathrm{wt} . \%$, there was a decrease in the number of bacteria to the value of 6-7 $\log _{10} \mathrm{CFU} / \mathrm{g}$, and it was observed that at such biocide doses, an increase in the temperature was not significant. A satisfactory effect
Fig. 7 Response surface of the influence of the exposure time to sodium percarbonate and the process temperature on the number of $E$. coli bacteria in poultry manure $(\mathrm{MS}=0.5025)$

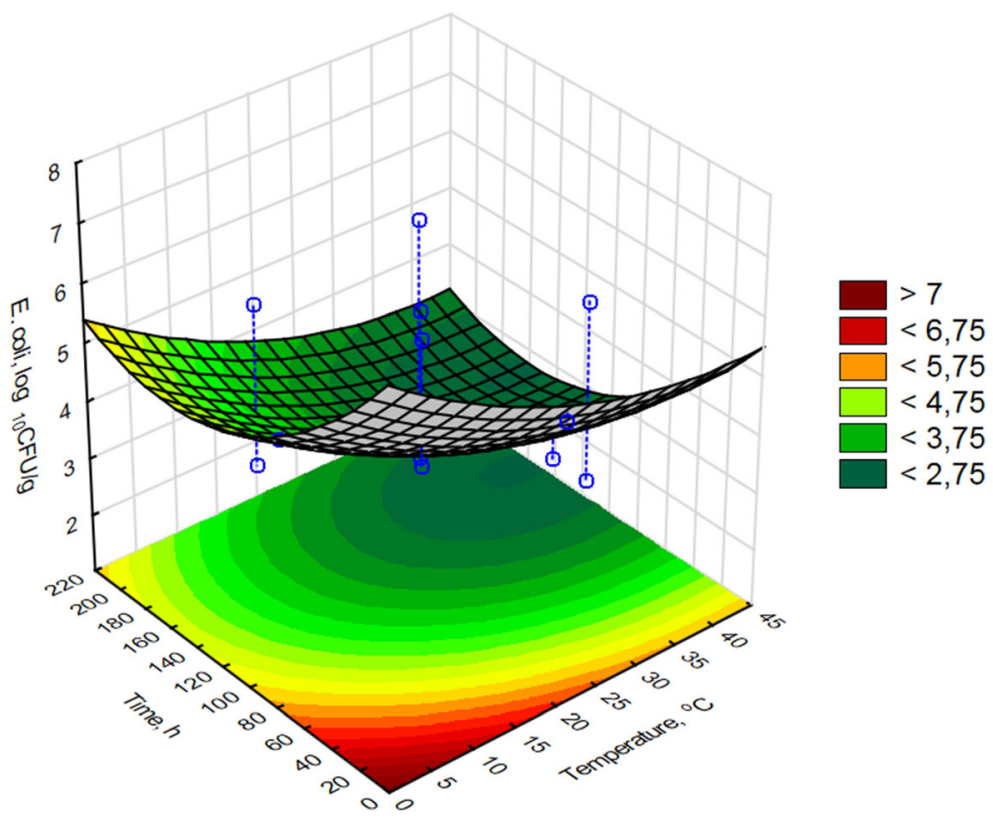


on the number of bacteria in the sample was obtained after adding more than $7 \mathrm{wt} . \%$ of sodium percarbonate. Reduction in the number of $E$. coli bacteria below $5 \log _{10} \mathrm{CFU} / \mathrm{g}$ was obtained at the temperature of $5{ }^{\circ} \mathrm{C}$, and reduction in the microorganisms to the level of $4 \log _{10} \mathrm{CFU} / \mathrm{g}$ at the temperature of approximately $15{ }^{\circ} \mathrm{C}$. The values of the number of bacteria below $3 \log _{10} \mathrm{CFU} / \mathrm{g}$ were observed at the biocide concentration of approximately $8 \mathrm{wt} . \%$ and the increase in the process temperature over $15^{\circ} \mathrm{C}$.

The mathematical description of Fig. 7, presenting the change in the value of $Z\left(E\right.$. coli $\left.\log _{10} \mathrm{CFU} / \mathrm{g}\right)$ as a function of $x_{2}$ (temperature) on $x_{3}$ (time) at the constant concentration of sodium percarbonate of $7.5 \mathrm{wt} . \%$, is presented in Eq. (6):

$$
\begin{aligned}
Z= & 15.8425-0.1055 \cdot x_{2}+0.0012 \cdot x_{2}^{2}-0.0351 \cdot x_{3} \\
& +0.0001 \cdot x_{3}^{2}-8.1304
\end{aligned}
$$

The conducted analysis showed that the number of E. coli bacteria decreased along with an increase in the temperature and the exposure time. At the constant biocide concentration of $7.5 \mathrm{wt} . \%$, the lowest number of bacteria of $<2.3 \log _{10} \mathrm{CFU} / \mathrm{g}$ was obtained for the samples incubated at the temperature of over $40{ }^{\circ} \mathrm{C}$ for at least $140 \mathrm{~h}$.

The determination of the general linear regression, based on Eq. (2), which describes a change in the number of $E$. coli bacteria $(Z)$ depending on a change in the input values, i.e. $x_{1}, x_{2}$ and $x_{3}$, is presented in the form of a polynomial (Eq. (7)). The general linear model (GLM) method and the values of the coefficients of determination presented in Table 4 are applied to estimate the full equation of the model.

$$
\begin{aligned}
\Sigma Z= & 14.3628-1.3921 x_{1} \\
& +0.0832 x_{1}^{2}-0.0780 x_{2} \bullet 0.0012 x_{2}^{2}-0.0352 x_{3} \\
& +0.0001 x_{3}^{2}-0.0091 x_{1} x_{2}-0.0011 x_{1} x_{3} \\
& +0.0004 x_{2} x_{3}
\end{aligned}
$$

The obtained value of the coefficient of determination for the complete model $\left(R^{2}=0.95\right)$ indicates a very good fit of the model to the experimental data. The high value of the adjusted coefficient $\left(R_{\text {adj }}^{2}=0.75\right)$ shows a good fit of the estimated equation of the model to the set of other experimental data.

The literature review indicates that there are no available studies confirming reduction pathogens in fresh animal manure using sodium percarbonate. The previous researchers had concluded that sodium carbonate $\left(\mathrm{Na}_{2} \mathrm{CO}_{3}\right)$ or sodium bicarbonate $\left(\mathrm{NaHCO}_{3}\right)$ can be used as an antimicrobial agent to eliminate $E$. coli in dairy cattle manure, only if the $\mathrm{pH}$ value is alkaline (Arthurs et al. 2001; Correll 1998). According to Correll (1998), the concentration of sodium bicarbonate required for inhibition $E$. coli decreased from 10 to 4 wt.\% for a $\mathrm{pH}$ value of 6.0 to 8.6 , respectively, when sodium hydroxide was added.

The microbiological tests conducted by Cuthbert et al. (1955) showed also that E. coli bacteria were able to survive even a few weeks after liming, i.e. at $\mathrm{pH}$ 5.8-7.8. The statistically determined survival time of $E$. coli in peaty soil, at the temperature of 4 and $20{ }^{\circ} \mathrm{C}$, was respectively 30 and 26.8 weeks (Paluszak et al. 2003), and the theoretical survival time of the bacteria, calculated with simple regressions, changed within the range of 21-49 weeks (Olszewska 2005). The dependence of the inactivation of the pathogens on the temperature was also confirmed by reviewing the available literature (Manyi-Loh et al. 2016). The survival time of E. coli at the temperature of $5-30{ }^{\circ} \mathrm{C}$ was determined to be 10-100 days.

\subsection{Determination of Macronutrients Content in Water Extracts}

The results of the $\mathrm{pH}$ value and macronutrients content which included total $\mathrm{P}, \mathrm{N}, \mathrm{Ca}, \mathrm{Mg}$ and $\mathrm{K}$ in poultry manure water extracts (sample R0-R2) using the ICPOES method are presented in Table 5.

Table 4 The value of coefficient of determination $R$ for the complete model according to GLM method

\begin{tabular}{llllllllll}
\hline Parameter & $R$ & $R^{2}$ & $R_{\mathrm{adj}}{ }^{2}$ & SS model & MS model & SS rest & MS rest & $F$ & $p$ Value \\
\hline E. coli $\log _{10} \mathrm{CFU} / \mathrm{g}$ & 0.95 & 0.90 & 0.75 & 31.6 & 9.00 & 3.51 & 3.50 & 6.00 & 0.02 \\
\hline
\end{tabular}

$S S$ predicted residual error sum of square, $M S$ mean square, $F$ statistics 
Table 5 Determination of $\mathrm{pH}$ and macronutrients in poultry manure water extracts using the ICP-OES method

\begin{tabular}{lrrr}
\hline Sample & \multicolumn{2}{c}{ R0 } & \multicolumn{2}{c}{ R1 } \\
\hline $\mathrm{pH}$ & 5.1 & 8.1 & 9.7 \\
$\mathrm{P}_{\mathrm{t}}, \mathrm{mg} / \mathrm{l}$ & $310.0 \pm 31.0$ & $66.9 \pm 6.7$ & $5.7 \pm 0.6$ \\
$\mathrm{~N}_{\mathrm{t}}, \mathrm{mg} / \mathrm{l}$ & $680.0 \pm 100.0$ & $1040.0 \pm 160.0$ & $860.0 \pm 130$ \\
$\mathrm{Ca}, \mathrm{mg} / \mathrm{l}$ & $332.0 \pm 33.0$ & $53.1 \pm 5.3$ & $936.0 \pm 94.0$ \\
$\mathrm{Mg}, \mathrm{mg} / \mathrm{l}$ & $189.0 \pm 19.0$ & $43.7 \pm 4.4$ & $119.0 \pm 12.0$ \\
$\mathrm{~K}, \mathrm{mg} / \mathrm{l}$ & $701.0 \pm 70.0$ & $622.0 \pm 62.0$ & $658.0 \pm 66.0$ \\
\hline
\end{tabular}

$R 0$ control sample, $R 17.5 \mathrm{wt} \%$ sodium percarbonate, $R 23.0 \mathrm{wt} \%$ calcium hydroxide

The obtained data showed a comparison of $\mathrm{pH}$ and macronutrients in water extracts before and after the addition of biocides into the fresh poultry manure. The $\mathrm{pH}$ values for water extracts were 5.1 for control sample $\mathrm{R} 0$ and 8.1 and 9.7 for samples $\mathrm{R} 1$ and $\mathrm{R} 2$, respectively. The recommended concentration of $\mathrm{CaO}$ or $\mathrm{Ca}(\mathrm{OH})_{2}$ is approximately $3 \mathrm{wt} \%$ for fresh manure and $1 \mathrm{wt} . \%$ for slurry (Heinonen-Tanski et al. 2006).

However, for complete deactivation of pathogens in organic waste, this amount of calcium compounds could be unsatisfactory. Hence, for hygienizing of chicken manure or sewage sludge with $\mathrm{CaO}$ or $\mathrm{Ca}(\mathrm{OH})_{2}$, the mixture should reach the temperature of at least $55{ }^{\circ} \mathrm{C}$ and a $\mathrm{pH}$ of 12 (Malej 2000).

The concentration of phosphorous in fresh chicken manure (R0) was $310.0 \mathrm{mg} / \mathrm{l}$ and decreased after its biological deactivation. The analysis proved that the content of phosphorus in the sample R1 with 7.5 wt.\% the green oxidizing agent $\left(2 \mathrm{Na}_{2} \mathrm{CO}_{3} \cdot 3 \mathrm{H}_{2} \mathrm{O}_{2}\right)$ was higher than in the sample R2 with 3.0 wt.\% $\mathrm{Ca}(\mathrm{OH}) 2$ and amounted to: $66.9 \mathrm{mg} / \mathrm{l}$ and $5.7 \mathrm{mg} / \mathrm{l}$, respectively.

The total nitrogen concentration in R1 $(1040.0 \mathrm{mg} / \mathrm{l})$ was also higher compared with R0 (680.0 mg/l) and R1 $(860.0 \mathrm{mg} / \mathrm{l})$. The lowest concentration of calcium was observed in R1 solution ( $53.1 \mathrm{mg} / \mathrm{l})$ and the largest in R2 (936.0 mg/l). The magnesium content for R1 (43.7 mg/l) was three times lower than R2 $(119.0 \mathrm{mg} / \mathrm{l})$ and four times lower than R0 (189.0 mg/l). The potassium concentrations were similar in all samples (701.0, 622.0 and $658.0 \mathrm{mg} / \mathrm{l}$ for R0, R1 and R2, respectively).

Assuming that the amount of sodium percarbonate required to deactivate $1 \mathrm{t}$ of chicken manure is $75 \mathrm{~kg}$, the cost of this agent would be $\$ 30$ per tonne of organic waste. Based on the current market prices, the cost of sodium percarbonate is approximately two-folds higher than $\mathrm{Ca}(\mathrm{OH})_{2}$, i.e. $\$ 400$ and $\$ 200$ respectively. Despite that, applying sodium percarbonate in hygienization of chicken manure may generate additional benefits. Sodium percarbonate treatment can be more effective for eliminating $E$. coli in fresh poultry manure compared with calcium hydroxide. The hygienization method using calcium compounds in the form of $\mathrm{CaO}$ and $\mathrm{Ca}(\mathrm{OH})_{2}$, whose biocidal properties are based on increasing $\mathrm{pH}>$ 12 and temperature $>50{ }^{\circ} \mathrm{C}$, leads to loss of nitrogen, which transforms into ammonia. There are also formed insoluble calcium phosphates which are not available for the root system of the plants. For that reason sodium percarbonate is much more suitable for agricultural applications and considered a possible green oxidant and environmentally friendly agent. When added into the soil, it increases the oxygen supply and releases the organic matter from organic waste. An additional benefit is that sodium percarbonate is used in the form granulated powder which is safe and easy to use.

\section{Conclusions}

Multiple microbiological tests were conducted concerning the content of microorganisms in the samples of poultry manure which, when applied directly as a fertilizer, can pose a serious threat to human life. The results of microbiological assessment confirmed a high content of Enterobacteriaceae pathogenic bacteria, including Escherichia coli bacteria, as well as a high content of fungi and moulds. The initial research into deactivation of pathogens in chicken manure through using a high temperature $\left(40-105^{\circ} \mathrm{C}\right)$ over a short time, i.e. $2 \mathrm{~h}$, showed a significant resistance of the microorganisms to such storing conditions. To effectively reduce a level of pathogens below the acceptable value in fertilizers, the influence of the temperature, the time and the amount of added sodium percarbonate of biocidal properties was analysed. The conducted optimisation of the process related to $E$. coli bacteria showed that an increase in the concentration of sodium percarbonate in the sample of chicken manure apparently decreased the number of the bacteria. It was also observed that the number of microorganisms lowered as the process temperature and the time of the contact of the biocide with manure increased. The value falls within the range of the acceptable number of Enterobacteriaceae bacteria, i.e. also E. coli, which, for natural fertilizers, is below 
$3 \log _{10} \mathrm{CFU} / \mathrm{g}$. The highest effectiveness in lowering the number of $E$. coli to the level of $2.3 \log _{10} \mathrm{CFU} / \mathrm{g}$ showed the setup with the following assumptions: biocide concentration of $7.5 \mathrm{wt} . \%$, temperature of $38^{\circ} \mathrm{C}$ and the time of $108 \mathrm{~h}$. Unfortunately, applying such a solution would a mean higher energy consumption in the process and would result in incurring additional costs for electricity. Nevertheless, the analysis showed that prolonging the time of the contact of manure with the biocide of the concentration of 7.5 wt.\% up to $208 \mathrm{~h}$ would enable obtaining an equally satisfying effect of reduction of pathogens to the acceptable level, at the ambient temperature of $22{ }^{\circ} \mathrm{C}$. Due to the economic effectiveness of the process, such a solution seems to be much more beneficial. Additionally, using sodium percarbonate as a green agent for deactivation of pathogens in chicken manure makes it more suitable for agricultural applications than the commonly used calcium hydroxide. Results of the concentration of phosphorous and nitrogen in poultry manure water extracts in sample with sodium percarbonate was significantly higher than the amount of this element determined in samples with calcium hydroxide.

The Response Surface Methodology enabled a statistical analysis of the obtained experimental data and the development of mathematical models of the analysed processes. Visualization of the data in form of 3D plots was helpful while discussing the effects of the conducted research.

The obtained results may be applied to develop an innovative method of hygienization of animal manures with a biocide, which would effectively reduce the number of pathogenic microorganisms, additionally being a substance safe for the natural environment and not bioaccumulated.

Funding Information This work was supported by the Ministry of Science and Higher Education, Republic of Poland (Statutory Activity of the Central Mining Institute, Task no. 11382019-140).

Open Access This article is licensed under a Creative Commons Attribution 4.0 International License, which permits use, sharing, adaptation, distribution and reproduction in any medium or format, as long as you give appropriate credit to the original author(s) and the source, provide a link to the Creative Commons licence, and indicate if changes were made. The images or other third party material in this article are included in the article's Creative Commons licence, unless indicated otherwise in a credit line to the material. If material is not included in the article's Creative Commons licence and your intended use is not permitted by statutory regulation or exceeds the permitted use, you will need to obtain permission directly from the copyright holder. To view a copy of this licence, visit http://creativecommons.org/licenses/by/4.0/.

\section{References}

Allievi, L., Colombi, A., Calcaterra, E., \& Ferrari, A. (1994). Inactivation of fecal bacteria in sewage sludge by alkaline treatment. Bioresource Technology, 49(1), 25-30. https://doi. org/10.1016/0960-8524(94)90169-4.

Arthurs, C. E., Jarvis, G. N., \& Russell, J. B. (2001). The effect of various carbonate sources on the survival of Escherichia coli in dairy cattle manure. Current Microbiology, 43(3), 220224. https://doi.org/10.1007/s002840010291.

Baki Unal, H., Bayraktar, H., Illkay Alkan, R., \& Cengiz Akdeniz, R. (2015). Evaluation possibilities of chicken manure in Turkey. Agricultural Engineering, 2(154), 5-14. https://doi. org/10.14654/ir.2015.154.116.

Barbusiński, K. (2008). Sodium percarbonate as an agent for effective treatment of industrial wastewater. Przemysl Chemiczny, 87(1), 33-37.

Bicudo, J., \& Goyal, S. M. (2003). Pathogens and manure management systems: a review. Environmental Technology, 24(1), 115-130. https://doi.org/10.1080 $/ 09593330309385542$.

Box, G. E. P., Hunter, J. S., \& Hunter, W. G. (2005). Statistics for Experilllenters. Design, innovation, and discovery. (2nd ed.). John Wiley \& Sons, Inc., Publication.

Chen, Z., \& Jiang, X. (2014). Microbiological safety of chicken litter or chicken litter-based organic fertilizers: a review. Agriculture, 4(1), 1-29. https://doi.org/10.3390 /agriculture4010001.

Correll, D. L. (1998). Role of phosphorus in the eutrophication of receiving waters: a review. Journal of Environmental Quality, 27(2), 261-266. https://doi.org/10.2134 /jeq1998.00472425002700020004x.

Dagnall, S., Hill, J., \& Pegg, D. (2000). Resource mapping and analysis of farm livestock manures - assessing the opportunities for biomass-to-energy schemes. Bioresource Technology, 71(3), 225-234. https://doi.org/10.1016 /S0960-8524(99)00076-0.

Diez-Gonzalez, F., Jarvis, G. N., Adamovich, D. A., \& Russell, J. B. (2000). Use of carbonate and alkali to eliminate Escherichia coli from dairy cattle manure. Environmental Science and Technology, 34(7), 1275-1279. https://doi. org/10.1021/es9910356.

European Lime Association (2009). Practical guidelines for disinfection with lime. Brussels. Retrieved from http://www. uspoultry.org/animal_husbandry/files/2009 0211 Influenza_UK_web.pdf.

Heinonen-Tanski, H., Mohaibes, M., Karinen, P., \& Koivunen, J. (2006). Methods to reduce pathogen microorganisms in manure. Livestock Science, 102(3), 248-255. https://doi. org/10.1016/j.livsci.2006.03.024.

Jiang, X., Morgan, J., \& Doyle, M. P. (2002). Fate of Escherichia coli $\mathrm{O} 157: \mathrm{H} 7$ in manure-amended soil. Applied and Environmental Microbiology, 68(5), 2605-2609. https://doi. org/10.1128/AEM.68.5.2605. 
Jung, K.-S., Heu, S.-G., Roh, E.-J., Kim, M.-H., Gil, H.-J., Choi, N.-Y., Lee, D. H., Lim, J. A., Ryu, J.-G., \& Kim, K.-H. (2013). Effect of temperature on survival of Escherichia coli O157:H7 and Listeria monocytogenes in livestock manure compost. Korean Journal of Soil Science and Fertilizer, 46(6), 647-651. https://doi.org/10.7745/kjssf.2013.46.6.647.

Kalembasa S, Kalembasa D, Makowiecki K. (1992). Polish patent PL 169484. Method of obtaining organic-mineral fertilizer from centrifuge sewage sludge; Polish Patent Office, Warsaw, December 1992 [in Polish].

Kelleher, B. P., Leahy, J. J., Henihan, A., O’Dwyer, T., Sutton, D., \& Leahy, M. (2002). Advances in poultry litter disposal technology - a review. Bioresource Technology, 83(1), 2736. https://doi.org/10.1016/S0960-8524(01)00133-X.

Kudva, I. T., Blanch, K., \& Hovde, C. J. (1998). Analysis of Escherichia coli $\mathrm{O} 157: \mathrm{H} 7$ survival in ovine or bovine manure and manure slurry. Applied and Environmental Microbiology, 64(9), 3166-3174.

Kyakuwaire, M., Olupot, G., Amoding, A., Nkedi-Kizza, P., \& Basamba, T. A. (2019). How safe is chicken litter for land application as an organic fertilizer?: A review. International Journal of Environmental Research and Public Health, 1, 123. https://doi.org/10.3390/ijerph16193521.

Larney, F. J., Yanke, L. J., Miller, J. J., \& McAllister, T. A. (2003). Fate of coliform bacteria in composted beef cattle feedlot manure. Journal of Environmental Quality, 32(4), 15081515.

Malej, J. (2000). Properties of sewage sludge and selected methods of their neutralisation, processing and utilisation. Annual Set The Environment Protection, 2, 69-101 Retrieved from http://old.ros.edu.pl/text/pp_2000_003.pdf. (in Polish).

Manyi-Loh, C. E., Mamphweli, S. N., Meyer, E. L., Makaka, G., Simon, M., \& Okoh, A. I. (2016). An overview of the control of bacterial pathogens in cattle manure. International Journal of Environmental Research and Public Health, 13(9). https://doi.org/10.3390/ijerph13090843.

Matusiak, K., Skóra, J., Borowski, S., Pielech-Przybylska, K., Nowak, A., Wojewódzki, P., Herman, J., Okrasa, M., \& Gutarowska, B. (2017). Threats/risks in poultry farms: microbiological contaminants, dust, odours and biological method for elimination. Ecological Engineering, 18(3), 184-193 10.12912/23920629/69373 [in Polish].

Mawdsley, J. L., Bardgett, R. D., Merry, R. J., Pain, B. F., \& Theodorou, M. K. (1995). Pathogens in livestock waste, their potential for movement through soil and environmental pollution. Applied Soil Ecology, 2(1), 1-15. https://doi. org/10.1016/0929-1393(94)00039-A.

Minister of Agriculture and Rural Development (2008). Regulation of 18 June 2008 on the implementation of certain provisions of fertilizers and fertilization, 119 Journal of Law [in Polish].

Mituniewicz, T., Piotrowska, J., Sowińska, J., Mituniewicz, E., Iwańczuk-Czernik, K., \& Wójcik, A. (2016). Effect of calcium peroxide $\left(\mathrm{CaO}_{2}\right)$ addition to poultry litter on the parameters of its physicochemical, microbiological and fertilising quality. Journal of Elementology, 21(4), 1327-1341. https://doi.org/10.5601/jelem.2016.21.1.1056.

Myers, R. H., Montgomery, D. C., \& Anderson-Cook, C. (2016). Response Surface Methodology: process and product optimization using designed experiments (4th ed.). John Wiley \& Sons, Inc., publication. https://doi.org/10.2307 $/ 1270613$.

Nicholson, F. A., Chambers, B. J., \& Smith, K. A. (1996). Nutrient composition of poultry manures in England and Wales. Bioresource Technology, 58, 279-284.

Nicholson, F. A., Groves, S. J., \& Chambers, B. J. (2005). Pathogen survival during livestock manure storage and following land application. Bioresource Technology, 96(2), 135-143. https://doi.org/10.1016/j.biortech.2004.02.030.

Olszewska, H. (2005). Hygienic aspects of agricultural utilization of slurry. University of Science and Technology in Bydgoszcz. https://kpbc.umk.pl/publication/46276. [in Polish].

Omeira, N., Barbour, E. K., Nehme, P. A., Hamadeh, S. K., Zurayk, R., \& Bashour, I. (2006). Microbiological and chemical properties of litter from different chicken types and production systems. Science of the Total Environment, 367(1), 156-162. https://doi.org/10.1016/j. scitotenv.2006.02.019.

Paluszak, Z., Ligocka, A., Breza-Boruta, B., \& Olszewska, H. (2003). The survival of selected fecal bacteria. Electronic Journal Od Polish Agricultural Universities, 6(J2).

Park, G. W., \& Diez-Gonzalez, F. (2003). Utilization of carbonate and ammonia-based treatments to eliminate Escherichia coli O157:H7 and Salmonella Typhimurium DT104 from cattle manure. Journal of Applied Microbiology, 94(4), 675-685. https://doi.org/10.1046/j.1365-2672.2003.01899.x.

Pavlostathis, S., \& Giraldo-Gomez, E. (1991). Kinetics of anaerobic treatment: a critical review. Critical Reviews in Environmental Control, 21(5-6), 411-490. https://doi. org/10.1080/1064338910938842.

Płonka, I., \& Pieczykolan, B. (2020). Waterborne pathogens. Detection and treatment. Chapter 8: Thermal methods, ultraviolet radiation, and ultrasonic waves for treatment of waterborne pathogens. Psychology applied to work: an introduction to industrial and organizational psychology, tenth edition Paul (Vol. 53). Butterworth-Heinemann, Elsevier. https://doi. org/10.1017/CBO9781107415324.004.

Popova, T. P., Marinova-Garvanska, S. M., Dobromirova Kaleva, M., Zaharinov, B. S., Gencheva, A. B., \& Baykov, D. B. (2014). Decontamination of sewage sludge by treatment with calcium oxide. International Journal of Current Microbiology and Aplplied Sciences, 3(9), 184-192.

Qu, G., Cai, Y., He, K., Gao, H., Xie, R., Chen, X., \& Ning, P. (2018). Adding calcium oxide combined with calcium peroxide for strengthening rapid biological drying of dairy cattle manure. Journal of Environmental Waste Management and Recycling, 1(2).

Quiroga, G., Castrillón, L., Fernández-Nava, Y., \& Marañón, E. (2010). Physico-chemical analysis and calorific values of poultry manure. Waste Management, 30(5), 880-884. https://doi.org/10.1016/j.wasman.2009.12.016.

Statistics Poland. (2017). Statistic yearbook of the Republic of Poland. Warsaw, Poland: Central Statistical Office. Retrieved from https://stat.gov.pl/en/\%0Atopics/statisticalyearbooks/statistical-yearbooks/ststistical-yearbookof\%0Athe-republic-of-poland-2017,2,17.html

Thomas, M., Białecka, B., \& Zdebik, D. (2017). Removal of organic compounds from wastewater originating from the production of printed circuit boards by UV-Fenton method. 
Archives of Environmental Protection, 43(4), 39-49. https://doi.org/10.1515/aep-2017-0044.

Tiquia, S. M., Richard, T. L., \& Honeyman, M. S. (2000). Effect of windrow turning and seasonal temperatures on composting of hog manure from hoop structures. Environmental Technology, 21(9), 1037-1046. https://doi. org/10.1080/09593332108618048.

Tofant, A., Željko, P., Matković, K., Hadina, S., \& Križanić, J. (2003). Pig slurry hygienization with hydrogen peroxidesilver complex, an environmentally acceptable disinfectant. Introduction ecologic problem. Veterianarski Archiv, 73(6), 345-353.

Unc, A., \& Goss, M. J. (2004). Transport of bacteria from manure and protection of water resources. Applied Soil Ecology, 25(1), 1-18. https://doi.org/10.1016/j.apsoil.2003.08.007.

USDA, A. M. S. (2014). Sodium carbonate peroxyhydrate. Technical evaluation report. Agricultural analytics division for the USDA National Organic Program. https://doi. org/10.1172/JCI38307.2496.

Williams, P. T. (1999). Waste treatment and disposal. New York: Wiley.

Witkowska, D., Chorąży, Ł., Mituniewicz, T., \& Makowski, W. (2010). Microbiological contamination of litter and air during rearing of broiler chickens. Water-Environment-Rural Areas, 2(30), 201-210.

Wu, D., Li, L., Zhao, X., Peng, Y., Yang, P., \& Peng, X. (2019). Anaerobic digestion: a review on process monitoring. Renewable and Sustainable Energy Reviews, 103, 1-12. https://doi.org/10.1016/j.rser.2018.12.039.

Publisher's Note Springer Nature remains neutral with regard to jurisdictional claims in published maps and institutional affiliations. 